\title{
HOW TO REACH THE SUMMIT WITHOUT FALLING OFF ${ }^{1}$
}

\author{
Every mountain top is within reach if you just keep climbing. \\ - Barry Finlay, Kilimanjaro and Beyond
}

Dr. Gil Gonzalez, CEO of Mission Critical Solutions (MCS), was exhausted. Three years of doctoral studies were coming to an end, all while running a business that spanned over 20 states and hundreds of employees. Achieving his doctorate was the summit he had aimed for educationally and personally, but what about the summit for his business aspirations? His interests had been divided over the last three years balancing his academic and business pursuits, but MCS would now have his full attention.

Mission Critical Solutions (MCS) was a leading-edge technology solutions provider, headquartered in Tampa, Florida. MCS provided a broad range of technology products and services organized in six core lines of business: 1. Information Technology, 2. Telecommunications, 3. Security, 4. Technology Infrastructure \& Specialty Contracting, 5. Audio Visual Solutions, and 6. Building Automation as further described in Exhibit 11.

What were the next steps in MCS' development from a small to a mid-size business? MCS was in an inbetween phase, too big to be considered small by some industry designations and too small to be considered mid-size or big in others. MCS had undergone substantial organizational change just the prior year, transforming from a traditional flat structured organization to a divisional structure. This change was made with growth objectives in mind.

Governments, both federal and local, often set-aside procurements that were restricted only to small businesses. Large companies had small business subcontracting goals required by their customers. And small often meant lean and competitive, with gutsy visionary owners willing to take business risks and margins that large businesses lacked an appetite for. Would all this be at risk in moving MCS into the mid-sized corporate world?

Gonzalez thought of this decision as akin to a fighter deciding to move up a weight class. Doing so would have created a new dynamic with larger and stronger opponents that had spent years perfecting their game in their own weight class. The statistics for fighters who had tried this "stepping up" were not encouraging.

\footnotetext{
${ }^{1}$ Copyright $($ C 2019, Muma Case Review. This case was prepared for the purpose of class discussion, and not to illustrate the effective or ineffective handling of an administrative situation. Names and some information have been disguised. This case is published under a Creative Commons BY-NC license. Permission is granted to copy and distribute this case for non-commercial purposes, in both printed and electronic formats.
} 


\section{IT Industry Summary}

MCS had supplied primary services to the Information Technology (IT) market, providing complex and mission-critical technology solutions to federal, state, and local governments, educational institutions, and commercial customers. The term technology commonly referred to society's application of scientific knowledge to solve practical problems in industry or commerce. IT could be defined as the utilization of computers, software, services and infrastructure to create, store, exchange and leverage information to achieve a specific objective. Included in the IT industry market were hardware, software, services, and telecommunications. According to IDC research the world IT market was approximately \$3.8 trillion in 2016, up from $\$ 3.7$ trillion the previous year. The U.S. market accounted for approximately $28 \%$ of the total, or slightly more than \$1 trillion ("IT Industry Outlook 2016," n.d.) (Exhibit 1).

\section{Competitive Landscape}

There were three principal business segments where MCS had competed: Professional Services, Building \& Electrical Technologies and Unified Communications.

\section{Professional Services (PS)}

Professional Services included any requirement whose primary offering was to provide dedicated personnel to support a customer on a full-time basis, usually over a twelve-month period or longer. This service crossed over multiple technologies. Competitors included:

- General Dynamics Information Technology (GDIT) was a large business systems integrator that principally supported government clientele, in information technology (IT), systems engineering, professional services and simulation and training. GDIT's primary growth occurred by focusing on large, highly technical, government opportunities and acquisitions of other businesses.

- The Centech Group, Inc. (CENTECH) was a small business provider of systems and solutions to the federal government. CENTECH's business growth was from federal government agency-wide, multiple award contracts that required a deep level of subcontractor and partner relationships to perform. CENTECH strategy was that of a manager of its business partners and they leveraged partners' technical and pricing expertise to win projects off these contracts.

\section{Building \& Electrical Technologies (BET)}

Building \& Electrical Technologies referred to individual technologies such as audio-visual, security systems, cameras, access control systems, fire alarms, building automation, electrical and low voltage cabling. Competitors included:

- AVI-SPL was a large business integrator of audio-visual and collaboration solutions for organizations of all types around the world. AVI's growth resulted principally through a merger with SPL.

- Miller Electric was a large national electrical contractor. Miller's growth was a result of its decision to focus on strategic client (construction builder/owner/architect) relationships that had final decision authority and not on opportunities available to the general electrical contractor community. 


\section{Unified Communications (UC)}

Unified Communications included the integration of enterprise communication services such as voice (telephone systems including IP telephony), audio, web \& video conferencing, and unified messaging (integrated voicemail, e-mail, SMS and fax). UC could encompass all forms of communications that were exchanged via a network as they became an integrated part of the network communications deployment. Competitors included:

- Carousel Industries was a large business that offered unified communications \& collaboration, security, networking, data center and cloud-based solutions. Carousel's growth strategy focused almost exclusively on commercial Fortune 500 companies.

Many of MCS's larger competitors, including General Dynamics and CENTECH were disadvantaged by not being able to fulfill the needs of clients across all areas of IT. Instead, these large companies ended up subcontracting out various products and services to other companies. The ability of MCS to utilize its multidivisional business model to meet more of the customers' needs was a framework that had allowed MCS to compete with larger companies across MCS’s three primary divisions.

As Gonzalez stated in a case study he authored in the Muma Case Review, "Even large businesses, such as General Dynamics, Boeing, Harris, L3, and IBM, did not self-perform the full spectrum of capabilities MCS offered; they have all hired MCS in the past to meet their clients' needs.” (Gonzalez, 2016).

\section{Market Size}

While MCS business had spanned both government and private sectors, the majority of MCS revenue had been generated from US federal, state, and local government funds. Furthermore, these revenues were contracted in two primary manners: one where MCS was the prime contractor, which meant MCS had a direct contract with the owner/end-user/agency to supply services or products, and the other where MCS was the subcontractor to some other prime contractor, meaning MCS had no contractual relationship with the owner/end-user/agency, but rather supported them through another business. The following breaks down key competitive differentiators within this government sector.

\section{Federal, State and Local Procurement}

A large majority of MCS business clients came from the government sector. There were three levels of government in the US: federal, state, and local. The total fiscal year 2018 (FY18) government-wide budgets for all three sectors was over $\$ 7$ trillion dollars annually. Federal spending for FY18 is estimated at $\$ 4.1 \mathrm{~T}$, state spending at $\$ 2.0 \mathrm{~T}$ and local spending at \$1.8T (Exhibit 2). When excluding entitlement programs, such as Social Security, Medicare, etc., the Department of Defense and the Department of Veterans Affairs had dominated the other federal agencies in number of contractual transactions and funds awarded and thus had been the largest customers in this market (Exhibit 3).

\section{Small vs. Large Business Procurement}

Of the $\$ 4$ trillion in federal government annual spending, approximately $\$ 225$ billion comprised the pool of funds that all contractors competed for. There were government funds and contracts reserved exclusively for small businesses, as detailed in Exhibit 4. Small business exclusive contracts represented approximately $\$ 80$ billion annually. 


\section{Competitive Differences Between Small and Mid/Large Business}

Both commercial and government acquisitions involved quantitative and qualitative benefits to small business. In the commercial marketplace, while not necessarily mandated by regulation, there were industry standards that influenced large commercial companies to restrict or give benefits to small businesses in certain procurements. This was more of a qualitative factor; whereby large commercial businesses saw this as a social good. The National Minority Supplier Development Council (NMSDC) was one such organization that had advanced business opportunities for certified minority business enterprises and connected them to corporate members (Exhibit 5). The US Small Business Administration (SBA) had wielded regulatory authority over government small business set-aside procurements and induced large businesses to utilize small businesses as subcontractors in non-restricted, full and open government procurements (Exhibit 6). Midsize and larger businesses did not have these procurement setaside advantages.

MCS had benefited from several subcategories of small business set-asides in government contracting programs, including the ones below (Exhibit 6):

- 8(a) Business Development

- HUBZone Program

- Small Disadvantaged Businesses

- All Small Mentor-Protégé Program

The North American Industry Classification System (NAICS) had been the standard used by federal statistical agencies in classifying business establishments for the purpose of collecting, analyzing, and publishing statistical data related to the U.S. business economy (Exhibit 7). These codes had been used by government procurement officials in determining whether a business was classified as small or large. Traditionally, some NAICS codes determined business size by average annual revenue, and others by number of employees.

MCS qualified under NAICS codes in its primary industries but had already outgrown several of these NAICS codes related to its lines of business referenced in the Exhibit 8 table.

\section{MCS Overview}

\section{MCS Background}

MCS was founded by Gonzalez in 1989 after realizing he had a passion for small business automation and a true entrepreneurial spirit. Gonzalez had recently graduated from the University of South Florida MBA program and was eager to put that knowledge to use. Little capital was required, and the business began operating out of his garage. MCS had recognized continuous growth over the last two decades and changed significantly from its humble garage beginnings. Based in Tampa, Florida, it had spanned 20 states, employed over 300 people and produced \$30 million in revenue (Exhibit 9). Gonzalez's depth and breadth of experience garnered MCS the title of the fastest growing privately owned technology firm in Tampa Bay four years running (“Services,” 2017).

In the early 1990's MCS primarily serviced commercial clients with personal custom computer sales and network cabling. The need for Structured Cabling Systems (SCS) became evident as network standardization evolved (Gonzalez, 2016). According to Paul Rosenberg in his article, "The Basics of Structured Cabling," a Structured Cabling System was "a complete system of cabling and associated hardware which provides a comprehensive telecommunications infrastructure. This infrastructure serves a wide range of uses, such as to provide telephone service or transmit data through a computer network." 
(Rosenberg, 2016) (Exhibit 10). SCS services were essential to the infrastructure of Local Area Network (LAN) development and MCS witnessed significant growth by providing this service to customers. This led to the decision to expand MCS's markets served to include the local government and school districts (Gonzalez, 2016).

In 2000, MCS took on a significant new business vertical by entering the federal government marketplace. This new vertical was highly competitive with many regulatory hurdles. During this period, local companies mainly purchased technology support from community-based IT companies, but the federal government contractors competed on a nationwide scale. Gonzalez described his career as being dedicated to changing the way small disadvantaged technology solutions businesses were perceived by government contracting organizations and large national contractors ("Services," 2017). It would have been difficult for MCS to survive in this arena without developing a new business approach to price competition and overall business growth.

\section{Mission/Vision}

MCS’s mission statement was:

To provide reliable, competitively priced, and superior mission critical IP-converged technology solutions to federal, state, and local governments, educational institutions, and commercial markets primarily in the continental United States (CONUS) and strategically outside the continental Unites States (OCONUS) as well as in forward support of Department of Defense (DoD) client initiatives within [its] six categories of capabilities. (Gonzalez, 2016).

Gonzalez admired several competitors including CENTECH, Miller Electric, and Carousel Industries, each for different reasons. MCS could set itself apart from competitors by providing services with integrity. MCS had already become highly valued by clients and recognized for doing the job the right way; Gonzalez had earned the respect and consideration of many clients in the industry. This didn't always mean offering the lowest price when compared to competitors' bids. Gonzalez also believed it was important to continually "obsolete yourself," in other words, always advance your current state of knowledge. This kept MCS on the cutting edge of technology and services that it provided. As Gonzalez described it, MCS had created a culture that was "dedicated to product agnostic solutions tailored to best fit our customer's needs, MCS is bringing tomorrow's technologies for today's challenges." ("Services," 2017).

\section{Competitive Advantages}

MCS had several competitive advantages that contributed to steady growth in its marketplace and for the most part these advantages played across all lines of business. The most significant advantage was its designation as a small business. This afforded MCS a competitive advantage by limiting competition to only other designated or certified small businesses.

Another important advantage was that of price. Even in competitions against large businesses, most companies were not willing to accept the relatively low profit margins that Gonzalez was willing to accept. Gonzalez's belief had been, price to the market and then execute for profit maximization. Vendors and subcontractors were more willing to negotiate with you after you had won the contract than before.

MCS had an appetite for risk. In general, MCS’s working philosophy had been: The more complicated the project and the higher the risks, the lower the number of competitors that would likely engage. 
An unwavering confidence in your ability could and should be transferred to your customer. Gonzalez never bid on a job that he truly didn't believe he could do. This applied to all jobs, even jobs he had never done before. This was true when MCS used airboats to traverse the frozen Saint Lawrence Seaway in the winter near Detroit to access island preserves to install remote communication towers for the Customs and Border Patrol as a subcontractor to Boeing. It was also true when MCS built and installed GPS based communication cabinets in remote and desolate areas across the US to replace radar tracking of airplanes for the FAA and ITT Corporation.

Another MCS competitive advantage was its location. When it came to federal contracting, a disproportionate number of government contractors were located in the Washington DC metro area (DC, Maryland, and Virginia) that supported the executive branch agencies who were headquartered there. This resulted in a high level of competition in that area. Because of this level the competition, MCS elected to compete outside of the Capital Beltway and focus on more removed locations where fewer competitors existed; thus, MCS's footprint across the US largely followed Air Force and Navy bases in more remote places with limited competitors.

\section{Leveraging MCS Strengths}

Gonzalez considered all the factors that positioned MCS to become a large business. MCS's diversity of business offerings were formidable for a small business. In addition, MCS had developed an extensive portfolio of customers, and a widely respected business ethos that had both proven to be impetuses for repeat business. For example, MCS had obtained additional awards with customers such as the Small Business Administration, Department of Veterans Affairs, Department of Homeland Security, Department of Defense, and the Department of Housing and Urban Development after successfully completing complex and high-profile contracts. Additionally, MCS had an advantage over many other small businesses in that MCS had available qualified personnel on staff who were ready to be assigned to new contracts (waiting on the bench), while many other small businesses needed to hire new personnel to fill new positions after an award. This was a tremendous benefit to its customers because MCS's customers were confident that the personnel assigned were qualified and available to perform the full scope of their respective responsibilities.

MCS employed, on average, 12-15 sales personnel who pursued new business and managing existing accounts. MCS's sales force had both "in period (short term)" and "long term” sales goals. A strategy that MCS employed was for sales people to pursue a mix of both. Basically, the difference between winning a \$2 million contract and winning a \$20 million contract was the amount of time that a sales person would need to spend on pursuit of the award. The duration of a $\$ 2$ million procurement was typically less than a $\$ 20$ million procurement (6 weeks vs. 6 months). MCS would refine its bid/no-bid decision processes to accommodate the increased investment in sales personnel's time, which would enhance the win probability for each business opportunity pursued. MCS already had the sales force it needed to accomplish such an expanded business development strategy. The negative to pursuing larger (higher valued) business opportunities was that more personnel would generally be needed to perform each contract awarded, which increased the overhead needed to support the additional staff. MCS's diverse portfolio, its proven history of success, its qualified personnel on staff, and its extensive sales force, were particularly unique among small businesses.

\section{Business Posture}

Over the years, MCS had refined itself into specific market segments that provided the best advantage in a competitive marketplace. 


\section{MCS's Primary Lines of Business}

MCS's primary focus had been the design, installation, and maintenance of IT related equipment and infrastructure in six major areas. Further explanation of these six business lines are provided in Exhibit 11. These six core lines of business were as follows:

- Information Technology (as a subsector of IT, this included primarily data information storage and transport)

- $\quad$ Structured Cabling

- Unified Communications (voice information storage and transport)

- Audio-Visual Solutions

- Security \& Life Safety Systems

- Electrical Distribution \& Specialty Contracting

\section{Growth Positioning}

Gonzalez diversified MCS into these six core lines of business to ensure that success would never be dependent on just one market sector, in observance of the conventional wisdom, "Don't put all of your eggs in one basket.” Many small businesses concentrated on a single line of business, but the marketplace for any business was never linear--customer needs changed with technology. Moving forward, MCS could have chosen to position itself to evolve into a large business by concentrating on one of its six lines of business and extinguishing the cost and effort of operating in the other five lines. Alternatively, MCS could have decided to start competing for larger (higher value) business opportunities in all six lines. Also, MCS could have aimed for employing a hybrid of the two strategies--pick the best revenue making lines, historically, and dissolve the rest to streamline growth pursuits.

\section{Current Business Mix}

MCS had approximately 70\% of its work in federal, state, and local government-based contracts and 30\% in commercial work. Continued positive future revenues in these market segments had been forecasted. Projections had shown an increase in the government sector budgets and most of MCS's commercial revenues were generated from construction related projects in Central Florida which had been projected to maintain this growth pattern for the near-term future. MCS revenue, broken out by line of business, by NAICS code designation and by percentage of revenue that each line of business had experienced, are displayed in Exhibit 12. Exhibit 13 further indicates the size and dollar value of federal government procurements reserved exclusively for small businesses. Understanding the revenue mix of these lines of businesses juxtaposed to their small business classifications could help determine the strategy for future growth positioning. Exhibits 8 and 12, identify which NAICS codes that MCS still participated in as a small business, and those that MCS had already outgrown. Each line of business involved specific NAICS codes, and knowing which lines involve NAICS codes that MCS could compete in as a small business offered determiners for deciding which lines of business to concentrate on in its business development strategy.

\section{Insider's Insights}

MCS was a small business wanting to be large while retaining benefits of a small business. Every organization had nuances that affected their decision processes. MCS had been a privately-owned small business from its inception in 1989. Gonzalez was an actively engaged entrepreneur who was invested in all principal decisions. In some ways, this limited the natural growth rate as decisions funneled upward 
and often logjammed at the top. The management structure was further complicated by different senior management styles. Gonzalez, as the CEO provided the vision, mission, and inspirational motivation of a transformational leader, while the COO emphasized effort, rewarded performance, and acted as a cop for rule breakers--all characteristics generally modeled by transactional leaders as described by B.M. Bass (Bass, 1990).

Gonzalez wanted to minimize potential obstacles to growth and in classic transformational style, coined the mantra: "I only have one mandatory rule, and this is, don't be dumb." His point was: employees were empowered to make reasonable and rational decisions consistent with the company's mission and vision. However, even despite this empowering exhortation from the CEO, there had still developed in MCS an overarching centralized organizational structure that, in practice, top managers made the decisions and mid-level managers carried them out. Formal authority was still the functional reality at MCS. To move from rhetoric to reality, the company needed to shift toward a decentralized organizational structure. This would allow the organization to become more flexible and responsive by empowering mid- and lower-tier managers to act more quickly and solve problems faster (Koehler, 2011).

\section{Recent Reorganization}

In June 2016, MCS reorganized and divided the company into three primary divisions: Unified Communications, Professional Services, and Building and Electrical Technologies.

The first division, Unified Communications (UC), provided voice communication systems hardware and software solutions (PBX, VoIP, Cloud, etc.). The second, Professional Services (PS), incorporated most of MCS's full-time telephony and IT support staff located on government facilities. The third, Building and Electrical Technologies (BET), supported physical infrastructure, such as voice/data and electrical cabling, building automation, and fire alarm and mass notification systems. Each division appointed a president, each of whom was now responsible for the division's (P\&L) and turnkey sales and operations.

MCS's organizational structure included a fourth, administrative group that supported all three divisions and included accounting, facilities, warehouse/inventory, and senior management (CEO, COO and CFO). The three division presidents reported directly to the COO, who in turn, was a direct-report to the CEO.

This divisional model was untested by MCS, but the belief had been that such a restructure would allow MCS to achieve more rapid and better targeted decision making.

\section{Decision Summary}

Having reflected on his twenty plus years of running MCS through all its various growth and developmental phases, Gonzalez pondered four courses of possible actions as follows: Do nothing, strategically grow in some areas, consider mergers and acquisitions, or build a strategic set of partners. All had positive points to consider; however, each alternative would shape a very different looking MCS.

\section{Do Nothing - Stay the Course}

To do nothing was the safe option. MCS had experienced steady growth by simply making tweaks to its business strategy and adding new business offerings or solutions as technology or markets changed. A pro to this strategy was that it was familiar to MCS and the management team and required very little change in business practices. A negative was that a very small proportion of the opportunities within the marketplace would be captured, and the transition from small to mid-sized or large would be slow. 


\section{Strategically Grow in Only Some Areas}

As described in Exhibit 8: MCS Small Business Status under NAIC System, MCS was small in some NAICS codes, and large in others. MCS could have tried to strategically grow each small business NAICS in a manner that allowed it to stay a small business. Since the NAICS codes were calculated over a 3-year average, MCS could selectively bid on opportunities assigned small business NAICS codes that provided the highest return on investment, while not exceeding the NAICS size limits. At the same time, MCS could bid on opportunities assigned NAICS codes in which it was already deemed large, putting no limits on its growth efforts. A benefit of this method was that it would allow MCS to remain small as long as possible, while growing other business elements and taking advantage of both sectors of business (small and large) and capitalizing on the efficiencies gained by growing the large business segments. A negative to this approach: it was likely to be difficult to manage the small business revenues to ensure the average revenues of those NAICS primary industries would not exceed the threshold limits. Another negative to purposely staying within particular NAICS size standard limits was that MCS would be restricting itself from opportunities which might otherwise provide additional revenue.

\section{Merger and Acquisition}

This strategy was to grow by merger and acquisition (M\&A) of other businesses. MCS could purchase other small businesses and their portfolios of small business contracts, providing MCS endless access to small business revenue even if MCS were no longer a small business itself by NAICS code standards. Such mergers and acquisitions permitted the transfer of small business contracts throughout the remaining life of those contacts, which was typically five years. A benefit of this method was that MCS would not have to balance revenue growth to remain a small business and could focus without restraint on any business industry growth area. A negative was the legal expense and the time required for business integration that absorbing another company would likely involve, in addition to, the potential companyculture-conflicts between the new company's employees and MCS's employees (e.g., seniority carry-over and possible reduced health care benefits coverage/increased costs). If employees did not buy into the change, it could initially have affected performance and satisfaction.

\section{Build a Strategic Team of Small Business Partners}

This strategy of building a strategic team of small business partners involved MCS taking advantage of the unique programs offered by the SBA and other government organizations that allowed large businesses to mentor other small businesses through programs like the SBA Mentor-Protégé program. Such programs would permit MCS access to small business acquisitions once it was no longer classified as small. Another approach was to partner with other small businesses through teaming agreements and subcontracts to those small business to maintain a portion of the work and revenues. A positive of this approach was that MCS could leverage its 20 plus years of business experience in small business bid and proposal development and its technical competencies to enhance other smaller business offerings and maintain a position in the small business arena indefinitely. A negative was the added costs burden that another, smaller company might bring, which could affect price competitiveness as well as the unknowns in bringing business culture, operations, communications and trust between two companies together.

Whatever the course, MCS had proven itself as a strong, successful small business. This proven track record of success gave Gonzalez confidence that the company could succeed regardless of which option or set of options it pursued. 


\section{References}

The ABC of structured network cabling. (2017, January 21). Retrieved from http://community.fs.com/blog/the-abc-of-structured-network-cabling.html

About NMSDC. (n.d.). Retrieved from http://www.nmsdc.org/about-nmsdc/

Bass, B. M. (1990). From transactional to transformational leadership: Learning to share the vision. Organizational Dynamics, 18(3), 19-31. https://doi.org/10.1016/0090-2616(90)90061-S

Finlay, B., \& Finlay, C. (2017). Kilimanjaro and beyond: A life-changing journey. Nepean, Ontario: Keep on Climbing Publishing.

Gonzalez, G.T. (2016). Divide or converge. Muma Case Review, 1(7), 1-23. https://doi.org/10.28945/3581

Government Contracting Programs | The U.S. Small Business Administration. (n.d.). Retrieved from https://www.sba.gov/contracting/government-contracting-programs

IT Industry Outlook 2016. (n.d.). Retrieved from https://www.comptia.org/resources/it-industry-outlook2016-final

Koehler, J. (2011) Pearson custom business resources: Human behavior and organization. Boston: Pearson Learning Solutions.

North American Industry Classification System (NAICS)(2017). Retrieved from https://www.census.gov/eos/www/naics/

Rosenberg, P. (2016). The basics of structured cabling. Retrieved from http://www.ecmweb.com/basics/basics-structured-cabling

Services. (n.d.). Retrieved from http://www.missioncriticalsolutions.net/services-solutions

Small business procurement - Final FY 2017 goals. (2016). Retrieved from https://www.sba.gov/sites/default/files/articles/FY2017 Final Agency Goals Spreadsheet 2016 1201.pdf

System for award management. (n.d.). Retrieved from https://www.sam.gov/ 


\section{Acknowledgements}

This case study research was completed by this team of EMBA students in the Muma College of Business at the University of South Florida with support and contributions by Dr. Gilbert Gonzalez, CEO of Mission Critical Solutions (MCS).

\section{Biographies}

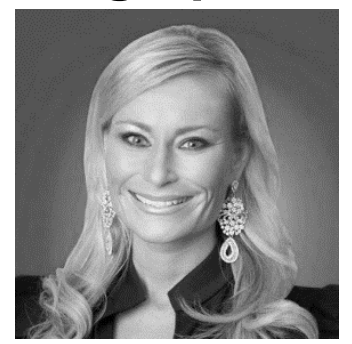

Robyn Hinchey is the Senior Military Healthcare Development Specialist with Chamberlain University. She markets pre and post licensure Registered Nursing programs to potential students who have a military affiliation. She is also responsible for creating partnerships with hospitals and nursing organizations. After eight years in the U.S. Air Force, Hinchey retired as a Captain in 2007. Hinchey attended the U.S. Air Force Academy in Colorado Springs, Colorado, and graduated in 1999 with a bachelor's degree in social sciences.

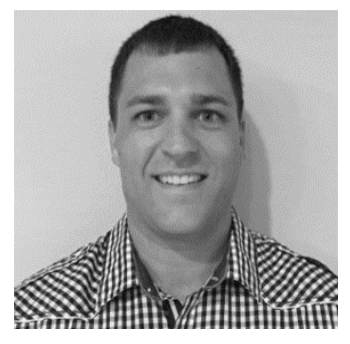

Krofton Owen is driven by education and life experience. He enjoys challenges that push him to new limits personally and professionally. He is now the vice president of business development at Industrial Maintenance Group, a company that specializes in industrial coating, fuel containment and waterproofing. He previously worked as the protective coatings specialist with Sherwin Williams, selling coatings and support services to building owners, industrial contractors and government project managers. Owen graduated from Capital University in Columbus, Ohio in 2004 with a bachelor's degree in business management.

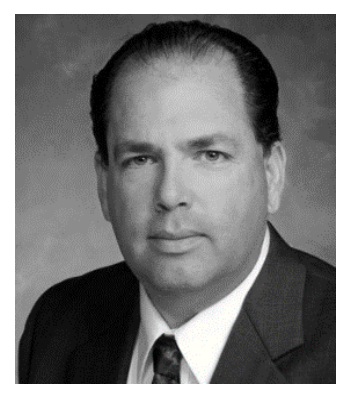

Scott Seigel is a Technical Expert for Siemens Government Technologies. As a Professional Engineer, LEED AP and Certified Energy Manager (CEM), his work delves into various methods of energy production including solar, wind, biomass and geothermal as well as energy savings through building controls, lighting and HVAC systems. He had served as Chapter President of the American Society of Mechanical Engineers (ASME), the American Society of Heating Refrigeration and Air Conditioning Engineers (ASHRAE) as well as Regional Vice Chair of Government Activities (GGAC) for ASHRAE Region XII. Scott graduated from USF in 1994 with a bachelor's degree in mechanical engineering (BSME). Scott has travelled to more than 40 countries.

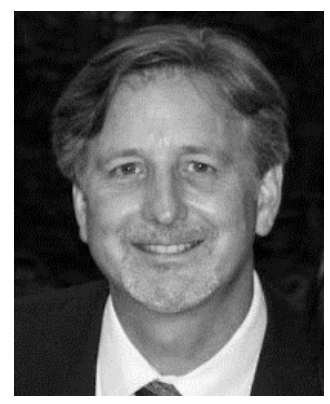

Doug Stacy is a student in the University of South Florida's Executive MBA program. He works fulltime as the Divisional President of Professional Services at Mission Critical Solutions in Tampa Florida, where he has been for the last 18 years. Doug is originally from Fairfax, Virginia, and prior to MCS, he worked for a number of defense contractors in the Washington, DC, metro area, from multinational corporations to privately held small businesses. He has undergraduate degrees from VA Tech and Procurement \& Contracts Management from Univ. of Virginia, and EMBA at Univ. of South Florida (Aug 2016 - May 2018). 


\section{Exhibit 1: Size of Global IT Industry}

\section{The Global Information Technology Industry: \$3.8 Trillion}

Estimated 2016 revenue at constant currency | Encompasses hardware, software, services and telecommunications

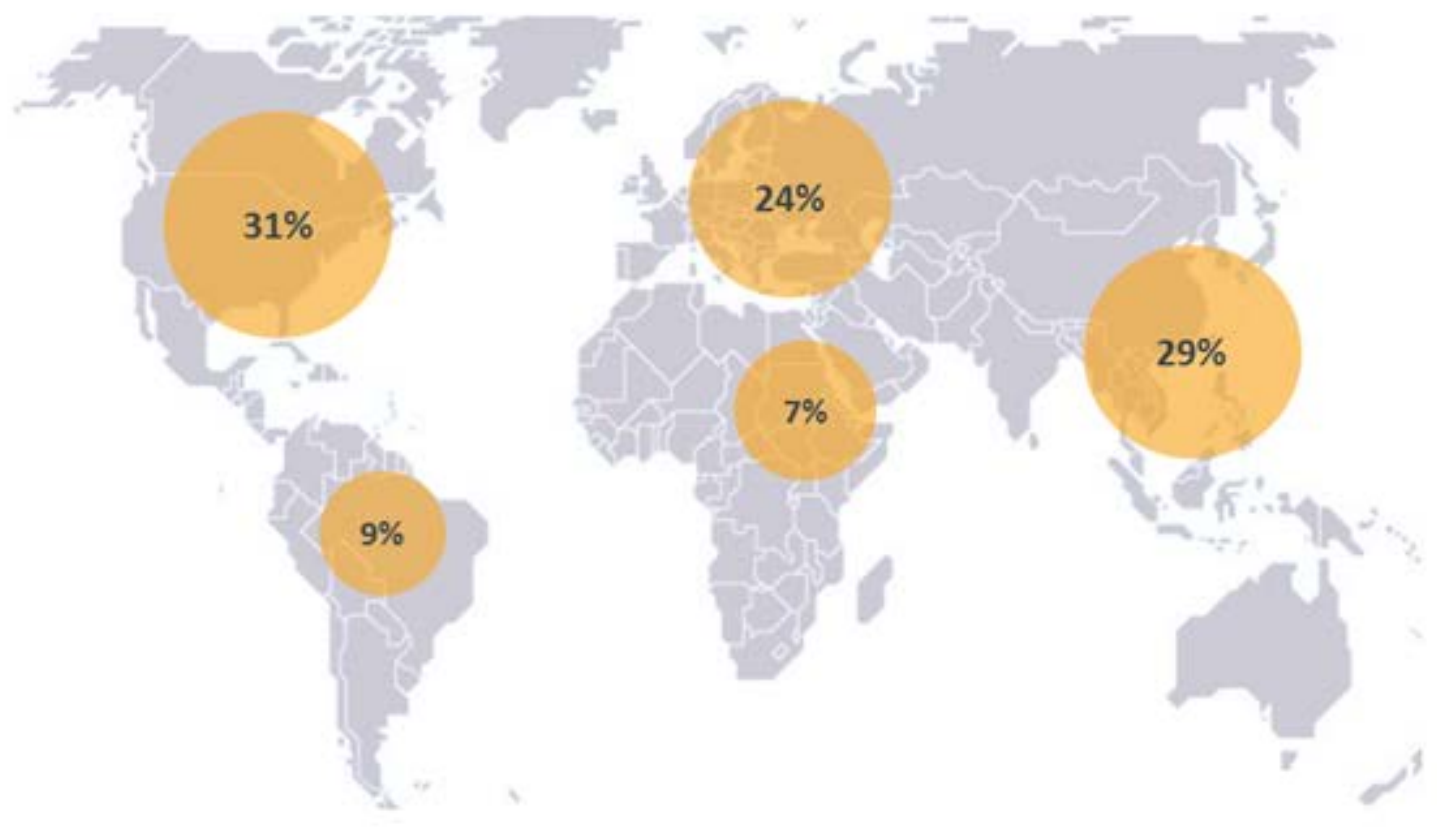

Source: https://www.comptia.org/resources/it-industry-outlook-2016-final 


\section{Exhibit 2: Current Government Spending in the US}

\begin{tabular}{|l|l|l|l|l|}
\hline & & & & \\
\hline 2015 & $\$ 3.69$ trillion & $\$ 1.68$ trillion & $\$ 1.70$ trillion & $\$ 6.44$ trillion \\
\hline 2016 & $\$ 3.85$ trillion & \$1.77 trillion & $\$ 1.71$ trillion & $\$ 6.67$ trillion \\
\hline 2017 & $\$ 4.06$ trillion & \$1.86 trillion & $\$ 1.73$ trillion & \$6.97 trillion \\
\hline $\mathbf{2 0 1 8}$ & $\mathbf{\$ 4 . 0 9}$ trillion & $\mathbf{\$ 1 . 9 5}$ trillion & $\mathbf{\$ 1 . 7 6}$ trillion & $\mathbf{\$ 7 . 1 1}$ trillion \\
\hline
\end{tabular}

*This includes entitlement spending, salaries, etc.

Source: https://www.usgovernmentspending.com/total_spending 


\title{
Exhibit 3: Small Business Procurement Goals for FY 2017
}

\author{
MOST FUNDS PAID OUT BY AGENCY - FY 2017
}

Customer agencies with which MCS has achieved repeat business are highlighted in yellow.

\section{Agency}

Department of Health and Human Services

Social Security Administration

Department of Defense

Department of Veterans Affairs

Department of Education

Department of Transportation

Department of Agriculture

Department of Housing and Urban Development

Department of Energy

Department of Homeland Security

National Aeronautics and Space Administration

U.S. Agency for International Development

Department of State

Department of Labor

General Services Administration

Department of Justice

National Science Foundation

Department of the Treasury

Department of Commerce

Department of the Interior

Environmental Protection Agency

Office of Personnel Management

Small Business Administration

Nuclear Regulatory Commission

Railroad Retirement Board

Export-Import Bank of the U.S.

Overseas Private Investment Corporation

Millennium Challenge Corporation

Corporation for National and Community Service

National Foundation on the Arts and the Humanities

Broadcasting Board of Governors

Executive Office of the President

Securities and Exchange Commission

Smithsonian Institution

National Archives and Records Administration

N/A

Federal Communications Commission

Consumer Financial Protection Bureau

Commodity Futures Trading Commission

GULF COAST ECOSYSTEM RESTORATION

COUNCIL (9533)

Federal Trade Commission

Government Accountability Office

\begin{tabular}{|c|c|}
\hline Funds Awarded & Number of Transactions \\
\hline$\$ 1,015,544,804,554$ & 238,946 \\
\hline$\$ 740,166,976,940$ & 203,116 \\
\hline$\$ 203,044,421,696$ & 2,442,996 \\
\hline$\$ 158,416,631,073$ & 954,033 \\
\hline$\$ 67,886,708,826$ & 566,744 \\
\hline$\$ 52,846,767,552$ & 180,072 \\
\hline$\$ 52,464,864,723$ & 495,029 \\
\hline$\$ 40,626,323,010$ & 161,381 \\
\hline$\$ 28,534,287,854$ & 19,294 \\
\hline$\$ 19,818,887,820$ & 166,597 \\
\hline$\$ 17,213,717,111$ & 42,487 \\
\hline$\$ 12,464,243,956$ & 14,416 \\
\hline$\$ 12,426,991,105$ & 72,261 \\
\hline$\$ 10,332,138,541$ & 15,939 \\
\hline$\$ 9,327,147,863$ & 152,730 \\
\hline$\$ 6,302,798,890$ & 120,943 \\
\hline$\$ 6,054,559,062$ & 23,149 \\
\hline$\$ 5,014,718,108$ & 21,122 \\
\hline$\$ 4,177,214,677$ & 27,983 \\
\hline$\$ 3,014,454,795$ & 90,575 \\
\hline$\$ 2,432,048,334$ & 16,785 \\
\hline$\$ 796,964,659$ & 1,956 \\
\hline$\$ 474,397,922$ & 133,305 \\
\hline$\$ 181,931,585$ & 1,641 \\
\hline$\$ 10,539,182,488$ & 100,224 \\
\hline$\$ 2,245,320,358$ & 2,324 \\
\hline$\$ 887,031,487$ & 363 \\
\hline$\$ 788,253,639$ & 693 \\
\hline$\$ 654,570,049$ & 2,762 \\
\hline$\$ 576,311,849$ & 3,958 \\
\hline$\$ 412,271,190$ & 6,357 \\
\hline$\$ 382,560,784$ & 2,617 \\
\hline$\$ 304,220,667$ & 2,319 \\
\hline$\$ 227,193,321$ & 2,856 \\
\hline$\$ 133,555,123$ & 1,185 \\
\hline$\$ 117,923,047$ & 594 \\
\hline$\$ 109,462,510$ & 720 \\
\hline$\$ 82,411,346$ & 578 \\
\hline$\$ 63,553,179$ & 624 \\
\hline$\$ 56,986,919$ & 14 \\
\hline$\$ 54,968,278$ & 647 \\
\hline$\$ 47,074,340$ & 908 \\
\hline
\end{tabular}




\section{Agency}

Equal Employment Opportunity Commission

Consumer Product Safety Commission

Court Services and Offender Supervision Agency for the

District of Columbia

Delta Regional Authority

National Labor Relations Board

Denali Commission

U.S. International Trade Commission

Pretrial Services Agency - CSOSA

Federal Election Commission

National Transportation Safety Board

National Credit Union Administration

Federal Mediation and Conciliation Service

Federal Mine Safety and Health Review Commission

Merit Systems Protection Board

Occupational Safety and Health Review Commission

Defense Nuclear Facilities Safety Board

Chemical Safety and Hazard Investigation Board

Federal Maritime Commission

Federal Labor Relations Authority

The Council Of The Inspectors General On Integrity And Efficiency

Selective Service System

Administrative Conference Of The U. S.

Federal Housing Finance Agency

National Capital Planning Commission

Library of Congress

$\begin{array}{rr}\text { Funds Awarded } & \text { Number of Transactions } \\ \$ 40,489,519 & 644 \\ \$ 21,410,766 & 1,107 \\ \$ 20,591,520 & 229 \\ \$ 13,737,863 & 55 \\ \$ 13,355,872 & 307 \\ \$ 12,706,874 & 112 \\ \$ 9,353,076 & 176 \\ \$ 7,742,834 & 226 \\ \$ 7,380,195 & 110 \\ \$ 7,028,891 & 216 \\ \$ 3,741,036 & 390 \\ \$ 3,436,310 & 81 \\ \$ 2,558,742 & 234 \\ \$ 2,418,766 & 257 \\ \$ 1,434,118 & 44 \\ \$ 1,217,834 & 52 \\ \$ 1,114,118 & 100 \\ \$ 1,070,304 & 64 \\ \$ 1,006,963 & 30 \\ \$ 986,854 & 58 \\ \$ 978,673 & 15 \\ \$ 288,931 & 13 \\ \$ 225,000 & \\ \$ 205,260 & \\ \$ 0 & \\ & \\ & \\ \$ & \end{array}$

Source: Prepared by the case writer from report generated by https://www.usaspending.gov/\#/ 
Exhibit 4: Small Business Procurement Goals for FY 2017

\begin{tabular}{|c|c|c|c|c|c|}
\hline \multicolumn{6}{|l|}{ Small Business Procurement - FINAL FY2017 Goals - as of 12/01/16 } \\
\hline \multirow[b]{2}{*}{ AGENCY } & \multicolumn{5}{|c|}{ Prime Contracting } \\
\hline & $\begin{array}{r}\text { Small } \\
\text { Business }\end{array}$ & SDB & WOSB & SDVOSB & HUBZone \\
\hline DEPT OF DEFENSE (9700) & $22.00 \%$ & $5 \%$ & $5 \%$ & $3 \%$ & $3 \%$ \\
\hline ENERGY, DEPARTMENT OF (8900) & $10.20 \%$ & $5 \%$ & $5 \%$ & $3 \%$ & $3 \%$ \\
\hline HEALTH AND HUMAN SERVICES, DEPARTMENT OF (7500) & $22.75 \%$ & $5 \%$ & $5 \%$ & $3 \%$ & $3 \%$ \\
\hline VETERANS AFFAIRS, DEPARTMENT OF (3600) & $28.50 \%$ & $5 \%$ & $5 \%$ & $3 \%$ & $3 \%$ \\
\hline NATIONAL AERONAUTICS AND SPACE ADMI NISTRATION (8000) & $16.00 \%$ & $5 \%$ & $5 \%$ & $3 \%$ & $3 \%$ \\
\hline HOMELAND SECURITY, DEPARTMENT OF (7000) & $35.50 \%$ & $5 \%$ & $5 \%$ & $3 \%$ & $3 \%$ \\
\hline GENERAL SERVICES ADMINISTRATION (4700) & $36.50 \%$ & $5 \%$ & $5 \%$ & $3 \%$ & $3 \%$ \\
\hline AGRICULTURE, DEPARTMENT OF (1200) & $49.00 \%$ & $5 \%$ & $5 \%$ & $3 \%$ & $3 \%$ \\
\hline JUSTICE, DEPARTMENT OF (1500) & $31.00 \%$ & $5 \%$ & $5 \%$ & $3 \%$ & $3 \%$ \\
\hline INTERIOR, DEPARTMENT OF THE (1400) & $53.50 \%$ & $5 \%$ & $5 \%$ & $3 \%$ & $3 \%$ \\
\hline STATE, DEPARTMENT OF (1900) & $25.08 \%$ & $5 \%$ & $5 \%$ & $3 \%$ & $3 \%$ \\
\hline COMMERCE, DEPARTMENT OF (1300) & $40.00 \%$ & $5 \%$ & $5 \%$ & $3 \%$ & $3 \%$ \\
\hline TREASURY, DEPARTMENT OF THE (2000) & $35.00 \%$ & $5 \%$ & $5 \%$ & $3 \%$ & $3 \%$ \\
\hline LABOR, DEPARTMENT OF (1600) & $34.63 \%$ & $5 \%$ & $5 \%$ & $3 \%$ & $3 \%$ \\
\hline TRANSPORTATION, DEPARTMENT OF (6900) & $50.00 \%$ & $5 \%$ & $5 \%$ & $3 \%$ & $3 \%$ \\
\hline ENVIRONMENTAL PROTECTION AGENCY (6800) & $40.00 \%$ & $5 \%$ & $5 \%$ & $3 \%$ & $3 \%$ \\
\hline EDUCATION, DEPARTMENT OF (9100) & $22.50 \%$ & $5 \%$ & $5 \%$ & $3 \%$ & $3 \%$ \\
\hline HOUSING AND URBAN DEVELOPMENT, DEPARTMENT OF (8600) & $39.00 \%$ & $5 \%$ & $5 \%$ & $3 \%$ & $3 \%$ \\
\hline AGENCY FOR INTERNATIONAL DEVELOPMENT (7200) & $11.50 \%$ & $5 \%$ & $5 \%$ & $3 \%$ & $3 \%$ \\
\hline SOCIAL SECURITY ADMINISTRATION (2800) & $37.05 \%$ & $5 \%$ & $5 \%$ & $3 \%$ & $3 \%$ \\
\hline OFFICE OF PERSONNEL MANAGEMENT (2400) & $28.75 \%$ & $5 \%$ & $5 \%$ & $3 \%$ & $3 \%$ \\
\hline NATIONAL SCIENCE FOUNDATION (4900) & $14.63 \%$ & $5 \%$ & $5 \%$ & $3 \%$ & $3 \%$ \\
\hline NUCLEAR REGULATORY COMMISSION (3100) & $32.00 \%$ & $5 \%$ & $5 \%$ & $3 \%$ & $3 \%$ \\
\hline SMALL BUSINESS ADMINISTRATION (7300) & 72.75\% & $5 \%$ & $5 \%$ & $3 \%$ & $3 \%$ \\
\hline
\end{tabular}

\begin{tabular}{|c|c|c|c|c|}
\hline \multicolumn{5}{|c|}{ Subcontracting } \\
\hline $\begin{array}{r}\text { Small } \\
\text { Business }\end{array}$ & SDB & WOSB & SDVOSB & HUBZone \\
\hline $34.00 \%$ & $5 \%$ & $5 \%$ & $3 \%$ & $3 \%$ \\
\hline $40.00 \%$ & $5 \%$ & $5 \%$ & $3 \%$ & $3 \%$ \\
\hline $33.00 \%$ & $5 \%$ & $5 \%$ & $3 \%$ & $3 \%$ \\
\hline $17.00 \%$ & $5 \%$ & $5 \%$ & $3 \%$ & $3 \%$ \\
\hline $31.70 \%$ & $5 \%$ & $5 \%$ & $3 \%$ & $3 \%$ \\
\hline $39.00 \%$ & $5 \%$ & $5 \%$ & $3 \%$ & $3 \%$ \\
\hline $29.00 \%$ & $5 \%$ & $5 \%$ & $3 \%$ & $3 \%$ \\
\hline $21.00 \%$ & $5 \%$ & $5 \%$ & $3 \%$ & $3 \%$ \\
\hline $40.00 \%$ & $5 \%$ & $5 \%$ & $3 \%$ & $3 \%$ \\
\hline $44.50 \%$ & $5 \%$ & $5 \%$ & $3 \%$ & $3 \%$ \\
\hline $36.00 \%$ & $5 \%$ & $5 \%$ & $3 \%$ & $3 \%$ \\
\hline $30.00 \%$ & $5 \%$ & $5 \%$ & $3 \%$ & $3 \%$ \\
\hline $26.00 \%$ & $5 \%$ & $5 \%$ & $3 \%$ & $3 \%$ \\
\hline $58.00 \%$ & $5 \%$ & $5 \%$ & $3 \%$ & $3 \%$ \\
\hline $48.00 \%$ & $5 \%$ & $5 \%$ & $3 \%$ & $3 \%$ \\
\hline $55.00 \%$ & $5 \%$ & $5 \%$ & $3 \%$ & $3 \%$ \\
\hline $31.00 \%$ & $5 \%$ & $5 \%$ & $3 \%$ & $3 \%$ \\
\hline $55.00 \%$ & $5 \%$ & $5 \%$ & $3 \%$ & $3 \%$ \\
\hline $18.00 \%$ & $5 \%$ & $5 \%$ & $3 \%$ & $3 \%$ \\
\hline $56.33 \%$ & $5 \%$ & $5 \%$ & $3 \%$ & $3 \%$ \\
\hline $55.00 \%$ & $5 \%$ & $5 \%$ & $3 \%$ & $3 \%$ \\
\hline $29.97 \%$ & $5 \%$ & $5 \%$ & $3 \%$ & $3 \%$ \\
\hline $40.00 \%$ & $5 \%$ & $5 \%$ & $3 \%$ & $3 \%$ \\
\hline $39.00 \%$ & $5 \%$ & $5 \%$ & $3 \%$ & $3 \%$ \\
\hline
\end{tabular}

Source:

https://www.sba.gov/sites/default/files/articles/FY2017 Final Agency Goals Spreadsheet 20161201.pdf 


\section{Exhibit 5: National Minority Supplier Development Council}

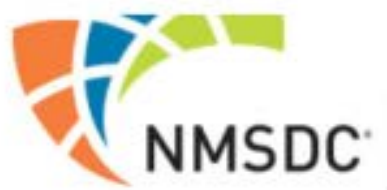

Search
National Minority Supplier Development Council
Advancing Business

Connections that Count

Q

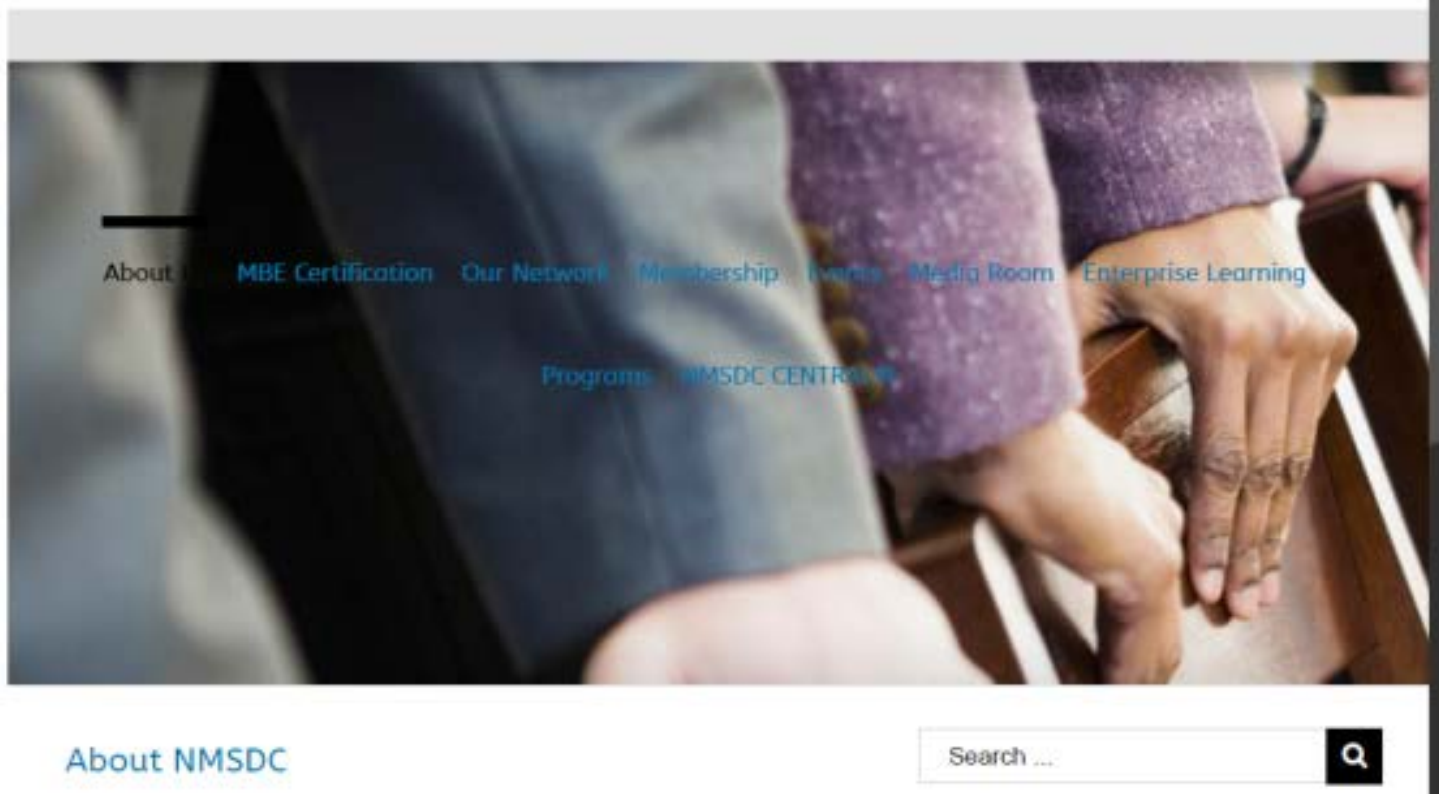

Mission:

The National Minority Supplier Development Council advances business opportunities for certified minority business enterprises and connects them to corporate members.

To achieve our mission, we will:

1. work through the NMSDC Network to support and facilitate MBE integration into corporate and public-sector supply chains:

2. build MBE capacity and capabilities through our programs and other education offerings: and
Share

ff Share:

in share

+4 share 39 
the country's leading corporate membership organizations. Whether you're a small minority-owned organization or a billion dollar powerhouse, we're committed to helping you solve the growing need for supplier diversity.

We do this by matching our more than 12,000 certifled minority-owned businesses to our vast network of corporate members who wish to purchase their products, services and solutions. Our corporate membership includes many of the largest public and privately-owned companies, as well healthcare companies, colleges and universities.

\section{The NMSDC network includes:}

- a national office in New York City

-23 affiliate regional councils nationwide

$-1,750$ corporate members and growing

We're proud of our unwavering commitment to advance Asian, Black, Hispanic and Native American suppliers in a globalized corporate supply chain.

Let us help you expand your business!

Consent to use photographic images:

Registration for, participation in and/or attendance at NMSDC meetings and other activities constitutes an agreement by the

(O) attendee to NMSDC's use and distribution (both now and in the future) of the registrant or attendee's name, likeness, image, voice, comments and/or appearance in any and all media, including the Internet, for any purpose consistent with the NMSDC's mission, without compensation.

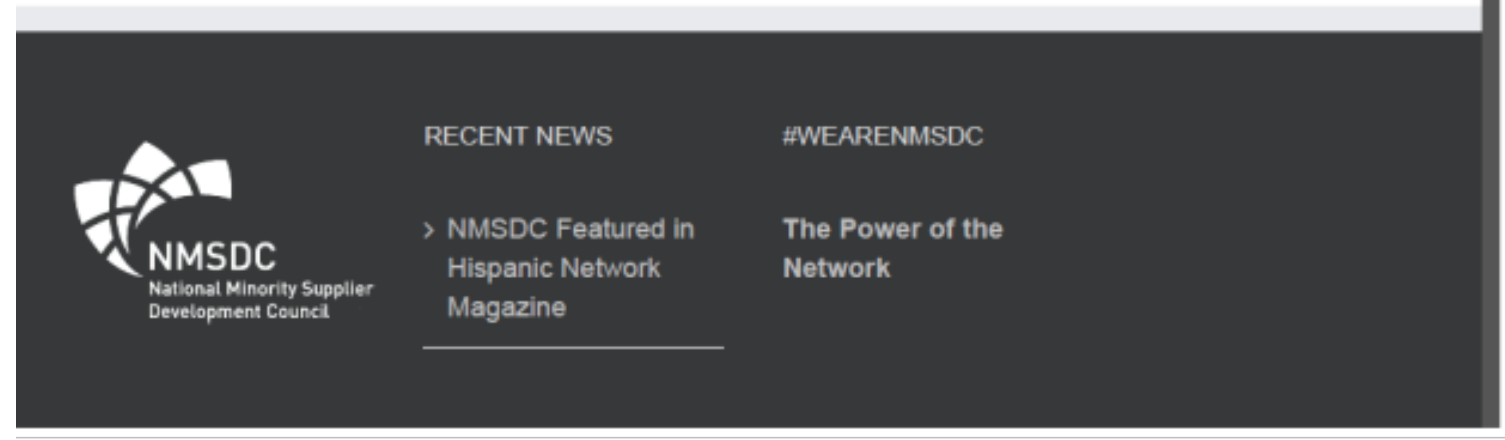

Source: NMSDC web site: http://www.nmsdc.org/about-nmsdc/ 


\section{Exhibit 6: The US Small Business Administration}

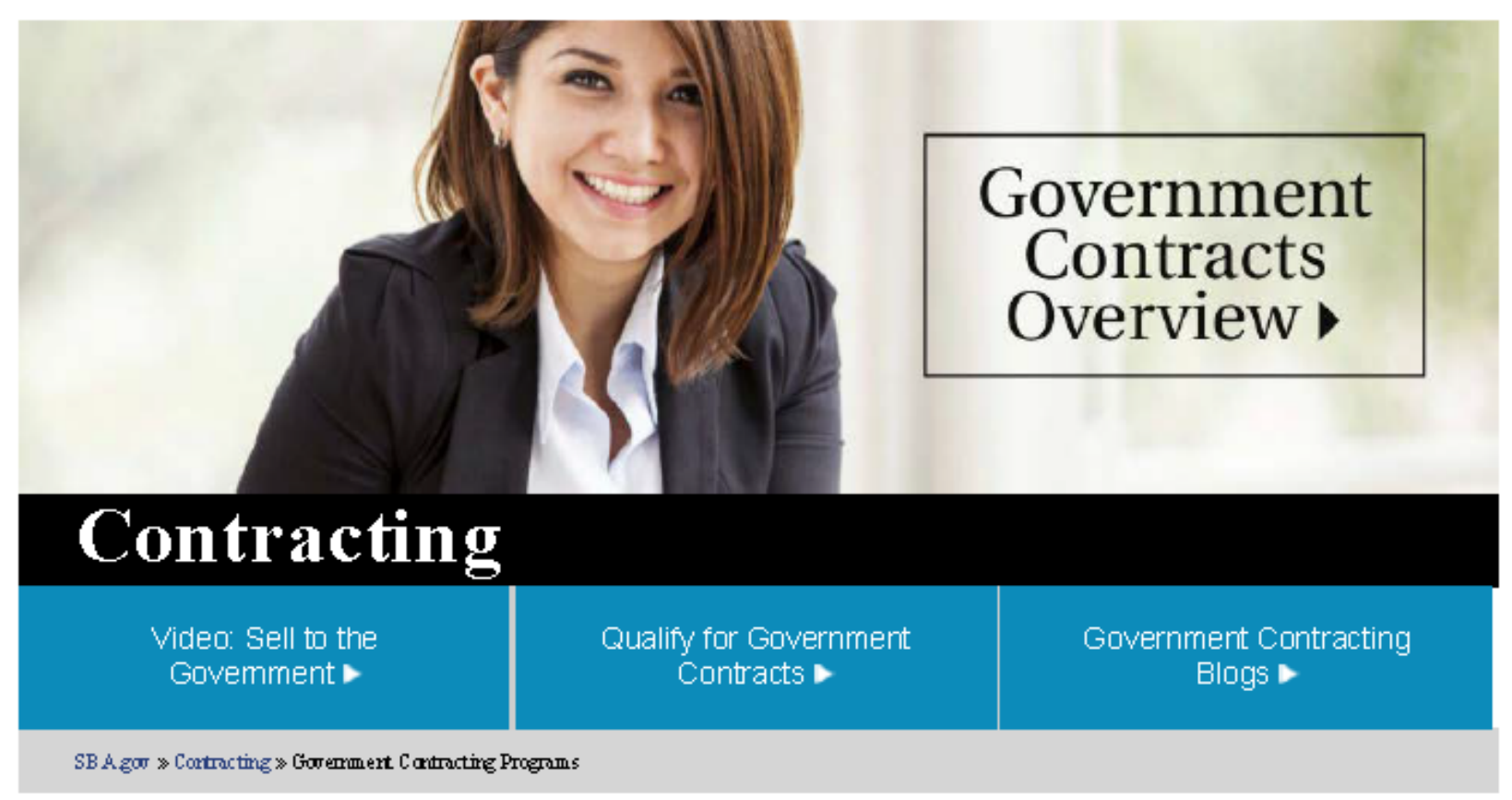

\section{Government Contracting Program s}

What is a Small Business Set Aside?

Small bus iness set- as ides are a pownerful tool for helping small businesses compete for and win federal contracts.

HUBZone Program
Women- Owned Small Busintesses

The Women-Owned Small Business (WOSB) Federal Contract program authorizes contracting officers to set aside certain feder al contract for eligible women-owned s mall businesses.

Serv ice-Disabled Veteran-Owned Businesses 8(a) Business Develop ment Program

Learn how SBAs 8(a) Business

Development Program helps small, dis advantaged businesses compete in the mark etplace.

Small Disadvantaged Businesses

Firms that are considered to besmall dis advantaged businesses can compete for certain federal contracting opportunities.
The Historically Underutilized Business Zones (HUBZone) program helps small businesses in urban and rural communities gain preferential access to federal procurement opportunities.
This program provides procuring agencies with the authority to set acquisitions aside for exclus we competition among service dis abled veter an-owned small business concerns.

\author{
All Small Mentor-Pro tégé \\ Program \\ This new program was established to \\ develop strong protégé firms through \\ mentor-provided business development \\ assistance, and to help protégés \\ successfully compete for gourernment \\ contracts. The SBA...
}

Source: SBA web site: https://www.sba.gov/contracting/government-contracting-programs 


\section{Exhibit 7: North American Industry Classification System}

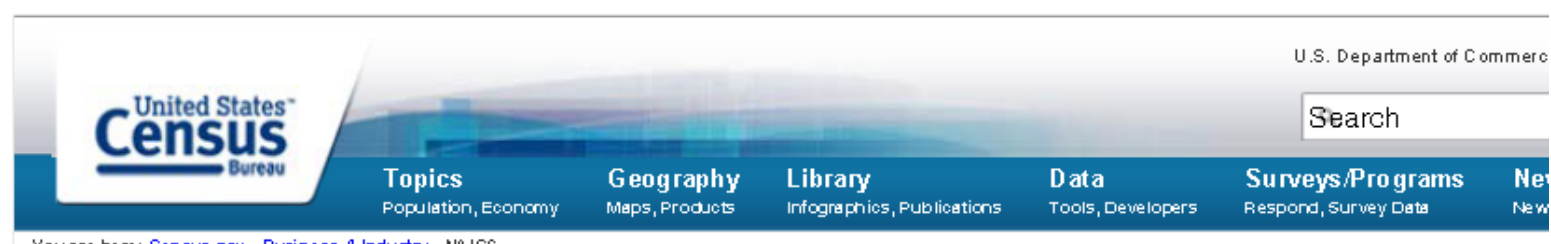

are: Census gou, Business \& Industry, NQ ICS

\section{North American Industry Classification System}

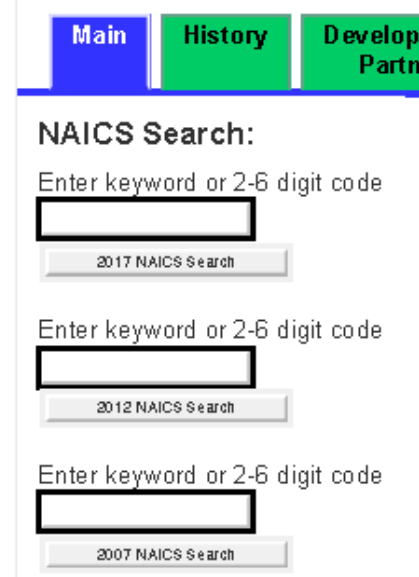

\section{Introduction to NAICS}

The North American Industry Classification System (NAICS) is the standard used by Federal statistical agencies in classifying business establishments for the purpose of collecting, analyzing, and publishing statistical data related to the U.S. business economy.

NAICS was developed under the auspices of the Office of Management and Budget (OMB), and adopted in 1997 to replace the Standard Industrial Classification (SIC) system. It was developed jointly by the U.S. Economic Classification Policy Committee (ECPC), Statistics Canada Er, and Mexico's Instituto Nacional de Estadistica y Geografia $B$, to allow for a high level of comparability in business statistics among the North American countries.

This official U.S. Government Web site provides the latest information on plans for NAICS revisions, as well as access to various NAICS reference files and tools. Additional information on the background and development of NAICS is available in the History section of this Web site.

Reference Files

\begin{tabular}{|l|}
\hline - 2017 NAICS \\
\hline - 2012 NAICS \\
\hline - 2007 NAICS \\
\hline - 2002 NAICS \\
\hline - 1997 NAICS \\
\hline - Concordances \\
\hline - Downloadable Files \\
\hline NAICS Update Process Fact \\
Sheet [PDF, 37KB] \\
\hline Contact Us \\
Emailus: naicsiocensusgov \\
\hline NAICS \\
\hline
\end{tabular}

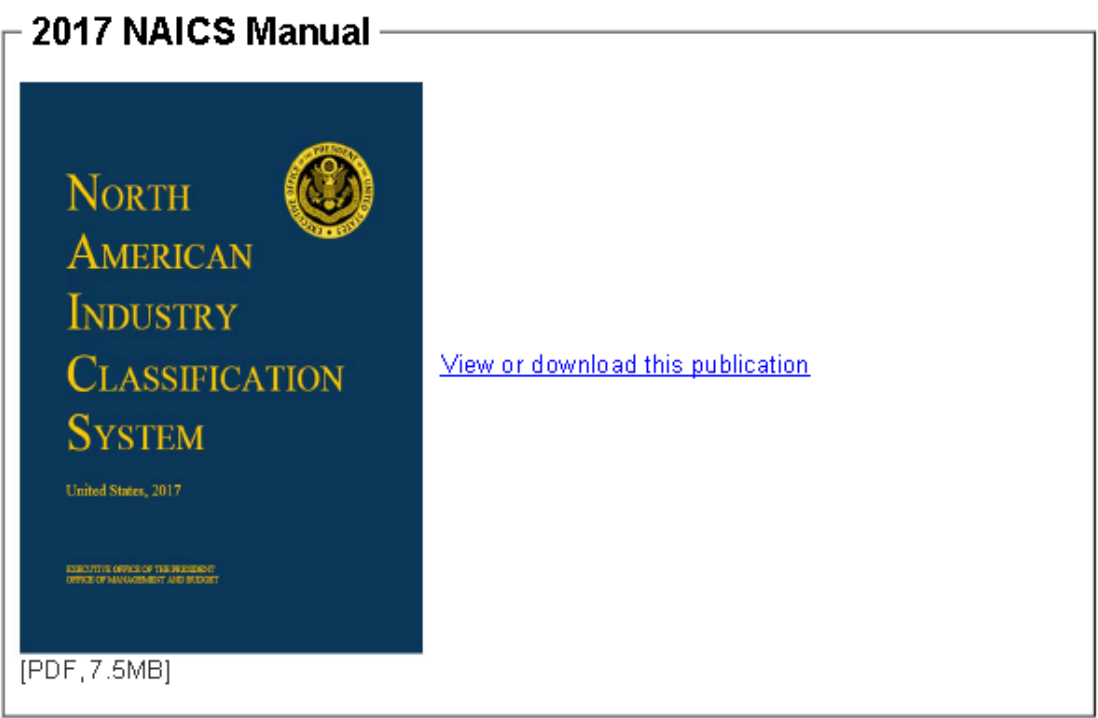

Source: https://www.census.gov/eos/www/naics/ 


\section{Exhibit 8: MCS Small Business Status under NAIC System}

(c) Offerors must complete the following representations when the resulting contract is to be performed inside the United States or its outlying areas. Check all that apply.

\begin{tabular}{|c|c|c|c|c|}
\hline $\begin{array}{l}\text { NAICS } \\
\text { Code }\end{array}$ & Name & NAICS Exception & Size Standard & $\begin{array}{c}\text { Small } \\
\text { Business? }\end{array}$ \\
\hline 236210 & $\begin{array}{l}\text { INDUSTRIAL BUILDING } \\
\text { CONSTRUCTION }\end{array}$ & & $\$ 36,500,000.00$ & $\mathrm{Y}$ \\
\hline 236220 & $\begin{array}{l}\text { COMMERCIAL AND } \\
\text { INSTITUTIONAL BUILDING } \\
\text { CONSTRUCTION }\end{array}$ & & $\$ 36,500,000.00$ & Y \\
\hline 237130 & $\begin{array}{l}\text { POWER AND COMMUNICATION } \\
\text { LINE AND RELATED } \\
\text { STRUCTURES CONSTRUCTION }\end{array}$ & & $\$ 36,500,000.00$ & $\mathrm{Y}$ \\
\hline 237990 & $\begin{array}{l}\text { OTHER HEAVY AND CIVIL } \\
\text { ENGINEERING CONSTRUCTION }\end{array}$ & 1 & $\$ 36,500,000.00$ & $\mathrm{Y}$ \\
\hline 237990 & $\begin{array}{l}\text { DREDGING AND SURFACE } \\
\text { CLEANUP ACTIVITIES } \\
\end{array}$ & 2 & $\$ 27,500,000.00$ & Y \\
\hline 238210 & $\begin{array}{l}\text { ELECTRICAL CONTRACTORS AND } \\
\text { OTHER WIRING INSTALLATION } \\
\text { CONTRACTORS }\end{array}$ & & $\$ 15,000,000.00$ & $\mathrm{~N}$ \\
\hline 334210 & $\begin{array}{l}\text { TELEPHONE APPARATUS } \\
\text { MANUFACTURING }\end{array}$ & & 1250 employees & Y \\
\hline 334310 & $\begin{array}{l}\text { AUDIO AND VIDEO EQUIPMENT } \\
\text { MANUFACTURING }\end{array}$ & & 750 employees & $\mathrm{Y}$ \\
\hline 334511 & $\begin{array}{l}\text { SEARCH, DETECTION, } \\
\text { NAVIGATION, GUIDANCE, } \\
\text { AERONAUTICAL, AND NAUTICAL } \\
\text { SYSTEM AND INSTRUMENT } \\
\text { MANUFACTURING } \\
\end{array}$ & & 1250 employees & Y \\
\hline 335921 & $\begin{array}{l}\text { FIBER OPTIC CABLE } \\
\text { MANUFACTURING }\end{array}$ & & 1000 employees & Y \\
\hline 423410 & $\begin{array}{l}\text { PHOTOGRAPHIC EQUIPMENT } \\
\text { AND SUPPLIES MERCHANT } \\
\text { WHOLESALERS }\end{array}$ & & 500 employees & Y \\
\hline 423430 & $\begin{array}{l}\text { COMPUTER AND COMPUTER } \\
\text { PERIPHERAL EQUIPMENT AND }\end{array}$ & & 500 employees & Y \\
\hline
\end{tabular}


HINCHEY, OWEN, SEIGEL, STACY

\begin{tabular}{|c|c|c|c|c|}
\hline $\begin{array}{l}\text { NAICS } \\
\text { Code }\end{array}$ & Name & NAICS Exception & Size Standard & $\begin{array}{c}\text { Small } \\
\text { Business? }\end{array}$ \\
\hline & $\begin{array}{l}\text { SOFTWARE MERCHANT } \\
\text { WHOLESALERS } \\
\end{array}$ & & & \\
\hline 511210 & SOFTWARE PUBLISHERS & & $\$ 38,500,000.00$ & $\mathrm{Y}$ \\
\hline 517110 & $\begin{array}{l}\text { WIRED TELECOMMUNICATIONS } \\
\text { CARRIERS }\end{array}$ & & 1500 employees & Y \\
\hline 517210 & $\begin{array}{l}\text { WIRELESS } \\
\text { TELECOMMUNICATIONS } \\
\text { CARRIERS (EXCEPT SATELLITE) } \\
\end{array}$ & & 1500 employees & Y \\
\hline 517911 & $\begin{array}{l}\text { TELECOMMUNICATIONS } \\
\text { RESELLERS } \\
\end{array}$ & & 1500 employees & Y \\
\hline 517919 & $\begin{array}{l}\text { ALL OTHER } \\
\text { TELECOMMUNICATIONS }\end{array}$ & & $\$ 32,500,000.00$ & Y \\
\hline 518210 & $\begin{array}{l}\text { DATA PROCESSING, HOSTING, } \\
\text { AND RELATED SERVICES } \\
\end{array}$ & & $\$ 32,500,000.00$ & Y \\
\hline 541330 & ENGINEERING SERVICES & 1 & $\$ 15,000,000.00$ & $\mathrm{~N}$ \\
\hline 541330 & $\begin{array}{l}\text { MILITARY AND AEROSPACE } \\
\text { EQUIPMENT AND MILITARY } \\
\text { WEAPONS } \\
\end{array}$ & 2 & $\$ 38,500,000.00$ & Y \\
\hline 541330 & $\begin{array}{l}\text { CONTRACTS AND } \\
\text { SUBCONTRACTS FOR } \\
\text { ENGINEERING SERVICES } \\
\text { AWARDED UNDER THE } \\
\text { NATIONAL ENERGY POLICY ACT } \\
\text { OF } 1992 \\
\end{array}$ & 3 & $\$ 38,500,000.00$ & $\mathrm{Y}$ \\
\hline 541330 & $\begin{array}{l}\text { MARINE ENGINEERING AND } \\
\text { NAVAL ARCHITECTURE } \\
\end{array}$ & 4 & $\$ 38,500,000.00$ & Y \\
\hline 541511 & $\begin{array}{l}\text { CUSTOM COMPUTER } \\
\text { PROGRAMMING SERVICES } \\
\end{array}$ & & $\$ 27,500,000.00$ & Y \\
\hline 541512 & $\begin{array}{l}\text { COMPUTER SYSTEMS DESIGN } \\
\text { SERVICES }\end{array}$ & & $\$ 27,500,000.00$ & Y \\
\hline 541513 & $\begin{array}{l}\text { COMPUTER FACILITIES } \\
\text { MANAGEMENT SERVICES } \\
\end{array}$ & & $\$ 27,500,000.00$ & Y \\
\hline 541519 & $\begin{array}{l}\text { OTHER COMPUTER RELATED } \\
\text { SERVICES }\end{array}$ & 1 & $\$ 27,500,000.00$ & $\mathrm{Y}$ \\
\hline
\end{tabular}




\begin{tabular}{|c|c|c|c|c|}
\hline $\begin{array}{l}\text { NAICS } \\
\text { Code }\end{array}$ & Name & NAICS Exception & Size Standard & $\begin{array}{c}\text { Small } \\
\text { Business? }\end{array}$ \\
\hline 541519 & $\begin{array}{l}\text { INFORMATION TECHNOLOGY } \\
\text { VALUE ADDED RESELLERS }\end{array}$ & 2 & 150 employees & Y \\
\hline 541712 & $\begin{array}{l}\text { RESEARCH AND DEVELOPMENT } \\
\text { IN THE PHYSICAL, ENGINEERING, } \\
\text { AND LIFE SCIENCES (EXCEPT } \\
\text { BIOTECHNOLOGY) }\end{array}$ & 1 & 1000 employees & Y \\
\hline 541712 & $\begin{array}{l}\text { AIRCRAFT ENGINE AND ENGINE } \\
\text { PARTS }\end{array}$ & 2 & 1500 employees & $\mathrm{Y}$ \\
\hline 541712 & $\begin{array}{l}\text { OTHER AIRCRAFT PARTS AND } \\
\text { AUXILIARY EQUIPMENT }\end{array}$ & 3 & 1250 employees & Y \\
\hline 541712 & $\begin{array}{l}\text { GUIDED MISSILES AND SPACE } \\
\text { VEHICLES, THEIR PROPULSION } \\
\text { UNITS AND PROPULSION PARTS }\end{array}$ & 4 & 1250 employees & Y \\
\hline 561210 & FACILITIES SUPPORT SERVICES & & $\$ 38,500,000.00$ & $\mathrm{Y}$ \\
\hline 811219 & $\begin{array}{l}\text { OTHER ELECTRONIC AND } \\
\text { PRECISION EQUIPMENT REPAIR } \\
\text { AND MAINTENANCE }\end{array}$ & & $\$ 20,500,000.00$ & $\mathrm{~N}$ \\
\hline
\end{tabular}

*Size is based on either average revenue over a 3-year average or number of employees

Source: https://www.sam.gov/ 


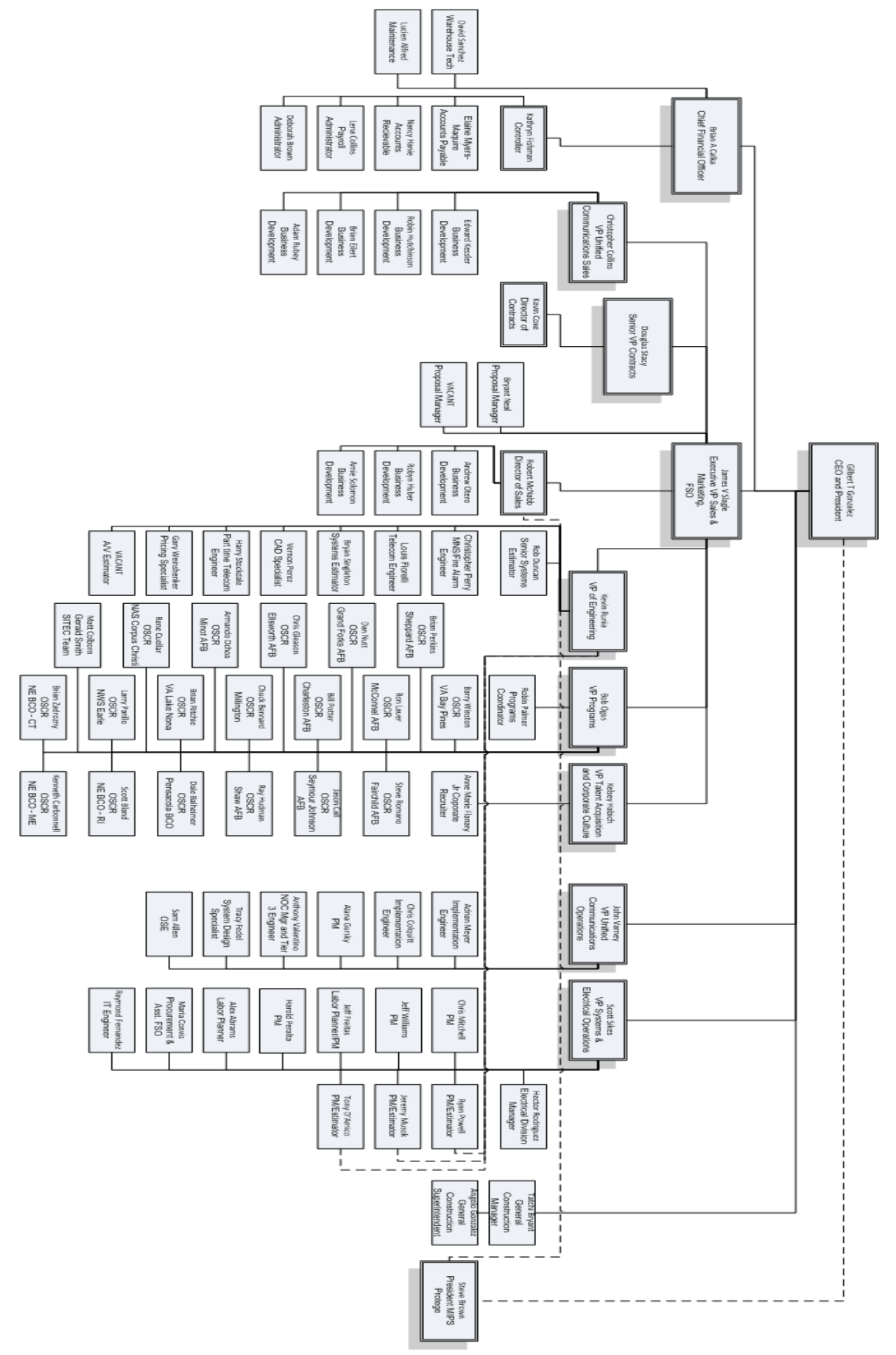

Source: Provided by MCS. Courtesy of James V. Slagle, COO, MCS 


\section{Exhibit 10: The ABC of Structured Network Cabling}
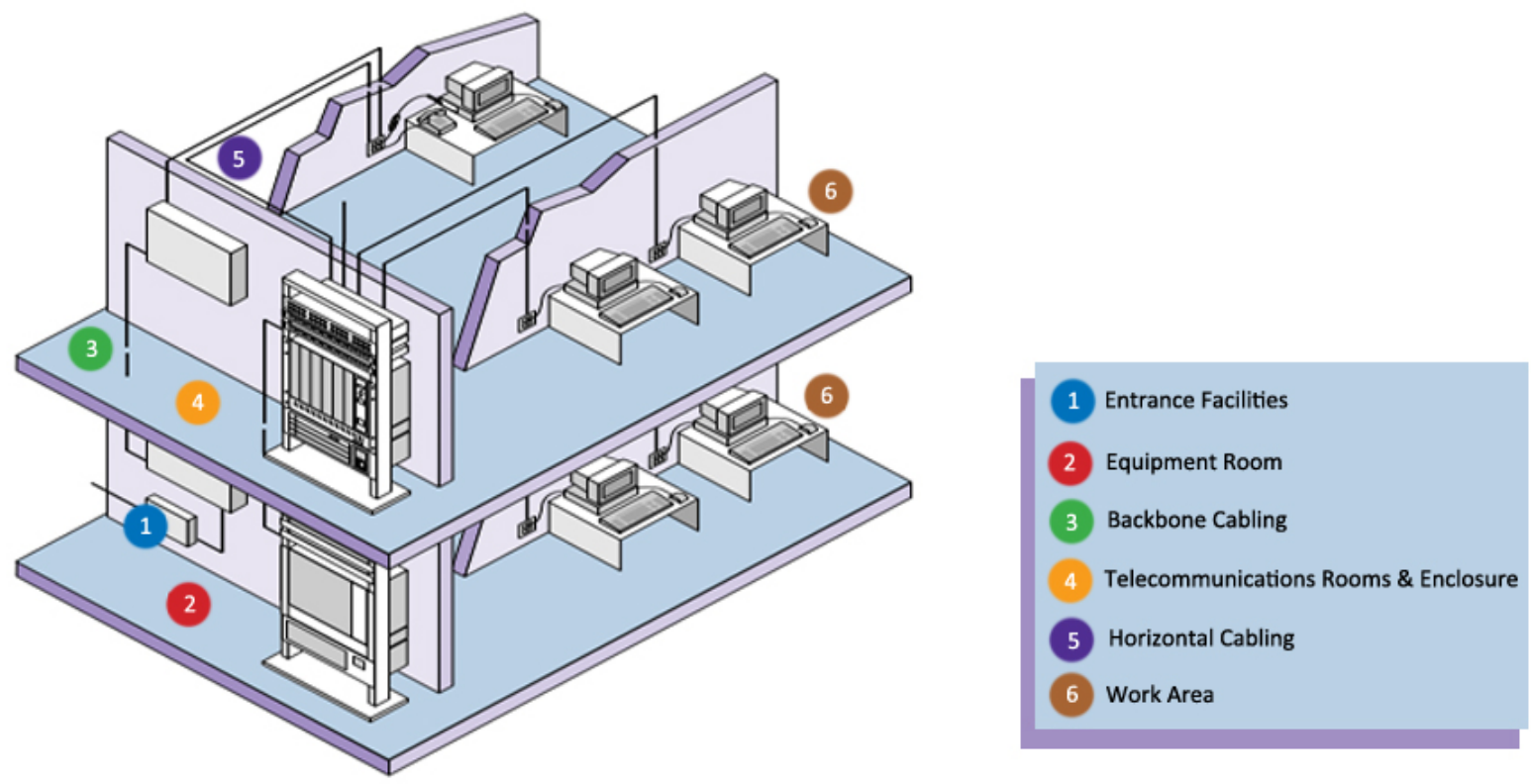

Source: http://community.fs.com/blog/the-abc-of-structured-network-cabling.html 


\section{Exhibit 11: Brief Description of MCS's Fields of Technology}

These descriptions are offered to provide insight into how MCS operates within each field.

Information Technology

MCS's IT group provided services including professional services consisting of assessment, design, planning, staging, configuration, and installation of IT Infrastructure.

\section{Structured Cabling (SC)}

MCS's SC group provided services including cabling infrastructure, ranging from small data center installations to large-scale campus and base-wide backbone infrastructure.

\section{Unified Communications (UC)}

MCS’s UC group provided services including design, integration, installation, maintenance and management. When UC provided messaging, conferencing, IM, mobile integration, video, or audio, all solutions were leveraged to provide the client state of the art IP systems and to maintain MCS's presence with the client.

\section{Audio-Visual (MCS AV)}

Throughout its history, The AV solutions group took a comprehensive approach to MCS's audio-visual technology services by providing clients all the relevant information required to make the best decision regarding their current and future AV technology needs. The approach consisted of installing new AV equipment or migrating AV equipment from proprietary networks to agnostic systems while complying with the most current IT systems and security requirements.

\section{Electronic Security and Life Safety Systems (LSS)}

The MCS LSS group specialized in security and life safety systems. The diverse experience of the LSS group personnel allowed MCS to address specialized areas within the security and life safety systems technology fields not limited to perimeter intrusion systems and basic life safety.

\section{Electrical Distribution \& Specialty Contracting}

EDS group's offerings included engineering, installation, proactive preventive maintenance, design, and build services. MCS's EDS group maintained experienced technical personnel specializing in the system design, system testing as well as the maintenance of electrical systems.

Source: Interview with Gil Gonzalez on September 1, 2017 and from Muma Case Review "Divide or Converge" (Gonzalez, 2016). 


\section{Exhibit 12: MCS Revenue by Line of Business}

MCS Revenue by Line of Business identifies the average percentage of revenue that each line of business had experienced. Understanding the revenue mix of these lines of businesses juxtaposed to their small business classifications can help determine the strategy for future growth positioning.

MCS Revenue by Line of Business

\begin{tabular}{|l|l|c|c|c|}
\hline Line of Business & $\begin{array}{l}\text { Maximum Revenue or } \\
\text { Number of Employees to } \\
\text { be considered a Small } \\
\text { Business }\end{array}$ & $\begin{array}{c}\text { Corresponding } \\
\text { NAICS } \\
\text { Codes** }\end{array}$ & $\begin{array}{c}\text { Percentage } \\
\text { of } \\
\text { Revenue* }\end{array}$ & $\begin{array}{c}\text { Approx. } \\
\text { Annual } \\
\text { Revenue* }\end{array}$ \\
\hline $\begin{array}{l}\text { Information } \\
\text { Technology }\end{array}$ & $\begin{array}{l}\text { \$27.5M avg 3 years of } \\
\text { revenue }\end{array}$ & 541512 & $24 \%$ & $\$ 8 \mathrm{M}$ \\
\hline $\begin{array}{l}\text { Structured } \\
\text { Cabling }\end{array}$ & $\begin{array}{l}\text { \$15M avg 3 years of } \\
\text { revenue }\end{array}$ & 238210 & $11 \%$ & $\$ 4 \mathrm{M}$ \\
\hline $\begin{array}{l}\text { Unified } \\
\text { Communications }\end{array}$ & 1,500 employees & $28 \%$ & $\$ 9 \mathrm{M}$ \\
\hline $\begin{array}{l}\text { Audio- Visual } \\
\text { Solution }\end{array}$ & $\begin{array}{l}250 \text { employees or } \$ 27.5 \mathrm{M} \\
\text { avg 3 years of revenue }\end{array}$ & 423430,541512 & $8 \%$ & $\$ 3 \mathrm{M}$ \\
\hline $\begin{array}{l}\text { Security \& Life } \\
\text { Safety Systems }\end{array}$ & $\begin{array}{l}250 \text { employees or } \$ 27.5 \mathrm{M} \\
\text { avg 3 years of revenue }\end{array}$ & 541330,541512, \\
541519 & $5 \%$ & $\$ 2 \mathrm{M}$ \\
\hline $\begin{array}{l}\text { Electrical } \\
\text { Distribution \& } \\
\text { Specialty } \\
\text { Contracting }\end{array}$ & $\begin{array}{l}\text { \$36.5M avg 3 years of } \\
\text { revenue }\end{array}$ & 238210,237130 & $24 \%$ & $\$ 8 \mathrm{M}$ \\
\hline
\end{tabular}

Source: *Data provided by MCS. 
HINCHEY, OWEN, SEIGEL, STACY

\section{Exhibit 13: FY 2017 Federal Government Overall Small Business Contracts}

\begin{tabular}{|l|r|r|r|r|}
\hline Goal Category & \multicolumn{1}{|c|}{$\begin{array}{c}\text { Eligible } \\
\text { Dollars }\end{array}$} & \multicolumn{1}{c|}{$\begin{array}{c}\text { Actual } \\
\text { Dollars* }\end{array}$} & \multicolumn{1}{c|}{ Goal \% } & $\begin{array}{r}\text { Actual \% } \\
\text { Achieved }\end{array}$ \\
\hline Small Business & $\$ 225.2 \mathrm{~B}$ & $\mathbf{\$ 4 5 . 4 B}$ & $23 \%$ & $20.15 \%$ \\
\hline Small Disadvantaged Business & $\$ 225.2 \mathrm{~B}$ & $\mathbf{\$ 1 7 . 2 B}$ & $5 \%$ & $7.63 \%$ \\
\hline Women Owned & $\$ 225.2 \mathrm{~B}$ & $\mathbf{\$ 9 . 4 B}$ & $5 \%$ & $4.15 \%$ \\
\hline Service Disabled Veteran Owned & $\$ 225.2 \mathrm{~B}$ & $\mathbf{\$ 7 . 8 B}$ & $3 \%$ & $3.47 \%$ \\
\hline Certified HUBZone Small Business & \$225.2B & $\mathbf{\$ 2 . 7 B}$ & $3 \%$ & $1.19 \%$ \\
\hline
\end{tabular}

*This includes only small business contracting opportunities and not entitlement or excluded program dollars.

Source: https://smallbusiness.data.gov/ 